\title{
The Potential Advantages of the Mandate System
}

\author{
By Jane Addams \\ Hull House, Chicago
}

I WILL give a little personal history of the feeling which many people in the neighborhood of Hull House had when the League of Nations was first talked about and when they believed, as simple people all over the world believed, that it was going to be the friend and the big brother of the weak scattered over the earth's surface and of those social groups who had not had a chance. Their experience registers something of the bitter disappointment at the moment which has constricted the hearts of many simple people.

For years at Hull House we have had a great deal to do with Italians who had left South Italy for South America to gather in the crops and to perform other hard agricultural labor. They used to have a very naive way of beginning on the South Side of the equator, to follow the ripening of the crops, as best they might, sometimes up into North Dakota, and then to go home for a few months and begin again. It was a very interesting scheme, and it would have worked very well but for one thing - that for so much of the time they were on the ocean, for so much of the time they were in remote parts of South American countries, sometimes in Central Mexico and sometimes even in our own states where they could not easily find an Italian Consul. They seemed to belong to a No Man's Land, where no man seemed to be very much concerned for their rights or their protection.

A Committee of such Italians came to me in the early days of the discussion of the League of Nations, and asked whether or not it was going to do something to take care of what we may call nomadic labor, of the labor which had

so little chance to be fostered by its own nationality and which was exploited, more or less, by all the other nationalities. These Italians felt very grateful to President Taft, because at one time when he was serving as a Federal Judge, in a case having to do with the West Virginia mines, he gave a decision in favor of some emigrants who had taken out their first papers and were therefore, in a sense, wards of the nation. He allowed them compensation for damages which in the steel mills and in the mines had systematically been denied them unless they were citizens of the United States. There was no money paid at that time to a widow or her little children living in Italy if the bread-winner were killed or injured in this country. Because of this decision, the Italians hoped that many things which had to do with nomadic labor might be taken care of when the League of Nations was established, and they were the more hopeful because Mr. Taft advocated it.

\section{Economic Aspects of League}

Then there are other aspects of the League of Nations which came very near home to one who had to do with immigrants, many of whom came to this country in search of more protection and more freedom than they were able to find at home. In the minds of some of these people whose daily lives are spent in hard labor there has been a bitter disappointment that the League of Nations in its first activities, and this would apply to the mandatory as it does to other commissions, has been so slow to have anything to do with the economic aspects of life. I am sure 
that many people must feel that the nation which ignores the economic resources of a country that is handed over to it under the mandatory provisions for protection and care, in a certain way begs the whole question. It is like being moral according to an old-fashioned test but refusing to measure up to the current test of the moment, to the test which after all determines whether or not one is moral contemporaneously. A nation may be content to apply a standard which was very good when colonial government had to do merely with political relations and had not yet openly acknowledged that it was also dealing with economic relations.

This may be illustrated in the case of Mesopotamia. In the secret treaties France was to have Mesopotamia, but England's troops won Mesopotamia, and England was able to produce a concession signed before the war for the oil interests there; and so when the thing was finally adjudicated, England was given the mandatory over Mesopotamia with seventy-five per cent of the oil, and France had the remainder, twenty-five per cent. The oil was apportioned and the mandate was given, (as all the other allocations, as I understand it, were made) by the Supreme Council and not by the League of Nations. The League of Nations merely undertakes to see that the annual reports are made and other matters carried out which are provided for under the section on mandatories.

But the economic test is at least under discussion. An Englishman has recently described what the result would be if England would say to Mesopotamia, "Of course, this oil must be developed. It belongs to the world; it does not belong to these tribes of Kurds and Arabs who happen to live in this immediate neighborhood.
It is needed for the heat and light and comfort of all the world. We will put our capital into it and pay our capital a good percentage, we will put experts here to develop these oil fields and we will pay our experts well. But after that is done, after all the nations of the earth have had an equal chance to buy this oil, the profits therefrom shall be returned, at least a goodly percentage of them, into the development of Mesopotamia." That would be fair and square, what we call a guardianship, analogous to what would happen to a child who had lost its parents and had been provided with a guardian.

It is the business of such a guardian to make a report to the probate judge. Let us assume that he makes a report on having kept the child in "law and order," that he makes a report on recognizing the child's right to vote and on getting him ready for his vote when he is twenty-one; he makes a report on all sorts of other things but he makes no report on the property which might be supposed to belong to the child. He says, "No, I prefer not to make a report on that." May we not say that there is a similar situation in these mandatory reports to be made to the Secretariat of the League?

I have been guardian of several children during the many years that I have lived at Hull House. Mothers have given them to me at the last desperate moment. Some of these children have been dependent and some of them have been "backward," and most of them have had a little property, usually what comes from an insurance. If there is one thing that is pathetic about these little bereft creatures it is that they are reaching out most eagerly to find some one to take the mother's place. They do not stand aside, but they make an imperious claim, "My mother is dead and you are now to be my mother." 
And they bring sometimes their little bags and baggages, after $I$ have made a very careful arrangement to have them live with some aunt or relative, and camp on the door-steps of Hull House saying, "You are my guardian, and, of course, I am going to live with you."

\section{The Mandatory System}

Something of that sort, it seems to me, is the situation implied in the mandatory system. If we admit that there are simple people in the world who are unable to govern themselves, and I think almost everyone dislikes to admit it, then we ought also to say, "Let that nation which is given the right of a mandatory also render some account of the economic resources which are found within the borders of the socalled backward nation."

Of course, it is a great thing to have publicity on these matters of colonial administrations. Perhaps the first probate court was established without having very much to do with property -although I imagine a lawyer would tell us that it had only to do with property and did not care much about what happened to the child-but certainly publicity was very good for the child's guardian. A great deal is to be gained in that the mandatory nation must report back once a year, and it may be possible that gradually property interests will also be accounted for.

The British Labor Party, in the early months of 1917, when that remarkable cry came out from Russia, "No annexations and no indemnities," said this: "Let the League of Nations take all of the colonies in tropical Africa, not only the German colonies but the Belgian colonies, and the French colonies and the Portuguese colonies. Let them administer them first for the benefit of the people who are there, and let the vegetable oils and other valuable things found there, be fairly allocated to all the nations of the earth."

The British Labor Party made this point in regard to the natural resources because they knew that these natural resources influenced the situation all of the time; the trader, the concessionaire, the planter and the rest of them continually made it very hard for the national administrators to stand firm in the interest of the backward nation. I think no one would doubt that there has been a splendid civil service administration of the British African colonies, and that, when things went wrong in those colonies-as perhaps it sometimes did as in other colonies-it was under the pressure of men from various nations who came in hoping to make financial gain out of the economic resources which were hidden in tropical Africa.

If the British Labor Party had been able to carry out this scheme, what would have followed? As an Englishman has recently said, there will have to be some sort of civil service training for men who are going to represent the League of Nations, and as such trained men made continuous inquiries into what was happening in this tropical South Africa, which had formerly belonged to at least four different nations, they might make a protest against the conscription of native troops, as they might make a protest against various things which are now happening in certain colonies in South Africa.

Above all they would certainly develop the international mind. They would develop a point of view which had to do, not with the good fortune or good will of one trader or of one nation, but primarily that the resources there should be developed in order to serve all the world; and secondarily, although I should like to put it first, that the people in that region should have every chance for development. Then we 
would have a probate court growing out of the mandatory system of the League of Nations, a probate court that had to do with all the aspects of a backward child, if we are pleased to call him that. After all, any guardian who should come into court and say, "I was interested, of course, in taking care of the child, but $I$ was also interested in lining my own pockets," would, I think, be thrown out of court, even the most corrupt one.

\section{Administration of the League}

One day years ago when we all began to talk about the Philippines, Mr. Dooley said to Mr. Hennessey: "We are all talking about the Philip" pines now as if we had known them from infancy, but only last week I didn't know whether they were islands or canned goods." I think something of the same sort is true about this island, Yap-and that other island which is full of phosphates. England and her colonies has had this second island allocated to them by the supreme council but they still have to give an account of their stewardship to the League of Nations, which will be made public, and all the world will gradually know what their administration is. They have already nationalized the phosphates-perhaps we can not strictly call them nationalized when Australia and New Zealand also have a share in them, but such an arrangement certainly is a move forward. Now is it going much further to say that the island should be administered, at least so far as allocation of phosphates is concerned, having in mind the farmers who can not raise grain to feed this hungry world because their soil lacks certain constituents? Could we not say that there are beginnings in various directions, in all sorts of subtle ways, toward an administration of the so-called backward peoples of the earth in the interest, first, that their possessions may be fairly distributed in the world-which is the way it will have to be put at present, I believe-and secondarily for the people themselves. Perhaps it will not be very long until the Assembly-and the hope of the League of Nations seems to me to reside in the Assembly - will make some trenchant suggestions having to do with these matters.

I am myself in a very curious position in regard to the League of Nations. I used to go around making long speeches for it before there was any Ieague of Nations at all and when one's mind could range for illustrations all over the world in a most marvelous fashion; and then the League of Nations was created and somehow my mouth was estopped, which was at least to the great advantage of my audiences. I never said a word against it, but I could not go about advocating it.

Then there was the meeting of the Assembly in Geneva, and suddenly all sorts of things cleared up. It seemed as if, after all, the nations of the earth could get together and discuss openly and freely and also kindly, for the most part, and even unselfishly, the genuine concerns of the world. The meeting of the Assembly was like the beginning of a new era, and perhaps this public discussion and this good will and this international intent was the beginning, after all, of a real League of Nations.

Of course, the Secretariat is doing wonderful things, and why not? It has been selected from the best men in all the nations, exactly as Colonel House picked the best men he could find and thus procured a wonderful Secretariat for the Peace Commission. But the crux of the situation will test the League as it did the Peace Commission, when something is brought before the Supreme Council which touches the 
individual interest of the nations that are represented there.

Of course, the Council of the League adjudicated the Finland and Sweden difficulties; but the test will come if something should go wrong in Syria with France's interest involved, that should have to come up before the Supreme Council. Mr. Hamilton Holt $^{1}$ has mentioned Ireland, I do not know where he ever got the courage, but he certainly had it with him when he said that the United States might bring up the question of Ireland to the

1 See page 1.
Supreme Council. I can only ask what would happen then.

And so one has to say that the mandatory, so far as it has gone, has been all to the good; publicity for the care of backward people, publicity for all treaties between nations which will in a specified time be invalid if they are not registered with the Secretariat at Geneva; publicity in international affairs coming from all directions and, perhaps, most of all, the free and open discussion of those matters which adhere to the interests of all nations.

\title{
The Mandate System of the League of Nations
}

\author{
By Denys P. Myers \\ Corresponding Secretary of World Peace Foundation; Assistant Director of League of \\ Nations News Bureau
}

$\mathrm{T}$

HE mandatory system began under the League of Nations as one of the best-attested ideas that has ever been officially realized on paper. During the war everybody was for it. General Smuts worked it out in a Ieague of Nations plan, published under the title of "A Practical Suggestion," and it was incorporated in the so-called American draft of the League of Nations Covenant. That draft was the primary basis of the so-called Miller-Hurst draft, from which the League of Nations Commission actually began work. The scheme appeared in that draft, and when the League of Nations Commission of the Peace Conference started to consider the Miller-Hurst draft, article by article, they found, before they reached the then Article XVII-which dealt with mandates - that the Council of Ten, that is, the premiers and the foreign ministers, had already passed a resolution on January 30, which for them was practically mandatory as to mandates.
As a result, in the League of Nations Commission there was very little discussion of the mandate article, because the resolution referred to had already been decided upon by those whose business it was to decide. It was first considered by the commission on February 8, 1919, at which time General Smuts moved the substitution of the resolution for the draft article. It was then sent to a drafting committee. The text was first adopted on February 10, for the draft of what we know as the Constitution of the League of Nations, as given out on February 14, 1919. The article, now Article XXII, was adopted in its final form on March 24. The suggestions of neutrals as to the Covenant had been heard on March 20 and 21, but they made no observations on that article.

From the time the Treaty was signed, June 28, 1919, until January 10,1920 , the Powers gave a great deal of attention among themselves to the matter of mandates. 